\title{
Characterization, expression and application of a zearalenone degrading enzyme from Neurospora crassa
}

\author{
Ke Bi ${ }^{1}$, Wen Zhang ${ }^{2}$, Zhizhuang Xiao ${ }^{2}$ and Dawei Zhang ${ }^{1 *}$
}

\begin{abstract}
A gene named zenc, encoding a zearalenone lactonase from Neurospora crassa, was over-expressed in Pichia pastoris. The zenc gene is 888-bp in length, encoding a 295-residue polypeptide. Purified ZENC has maximal activity at pH 8.0 and $45^{\circ} \mathrm{C}$, and is highly stable at pH 6.0-8.0 for $1 \mathrm{~h}$ at $37^{\circ} \mathrm{C}$. The activity of the secreted enzyme in shaken-flask fermentation was $40.0 \mathrm{U} / \mathrm{ml}$. A high-density fermentation of the ZENC-producing recombinant strain was performed in a 30-I fermenter and the maximal enzyme activity reached $290.6 \mathrm{U} / \mathrm{ml}$. The $\mathrm{K}_{\mathrm{m}}, \mathrm{V}_{\mathrm{max}}$ and specific activity toward zearalenone are $38.63 \mu \mathrm{M}, 23.8 \mu \mathrm{M} / \mathrm{s} / \mathrm{mg}$ and $530.4 \mathrm{U} / \mathrm{mg}$, respectively. ZENC can resist metal ions and inhibitors to some extent. We applied the enzyme into three different kinds of animal feed. On addition of ZENC (800 U) to distillers dried grains with solubles (DDGS), maize by-products and corn bran $(25 \mathrm{~g})$, the concentration of zearalenone was reduced by $70.9 \%, 88.9 \%$ and $94.7 \%$ respectively. All these properties of ZENC are promising for applications in the animal feed and food industries.
\end{abstract}

Keywords: Zearalenone degradation, Pichia pastoris, High-density fermentation, Animal feed, Maize

\section{Introduction}

Zearalenone (ZEN) is a nonsteroidal estrogenic mycotoxin which was first isolated by Stob et al. in 1962 and its structure was determined by Urry (Perry et al. 1970; Urry et al. 1966). It was initially used as a growth promoter in animal feed (Wilson et al. 1972), but now it is considered to have adverse effects, mainly on the reproduction of animals (Kleinova et al. 2002). This mycotoxin is a secondary metabolite of Fusarium species including $F$. graminearum, F. culmorum, F. equiseti, F. semitectum and F. crookwellense, particularly F. graminearum. All these species are soil fungi and common in temperate regions (Bennett and Klich 2003). ZEN contamination mainly occurs in maize and its co-products, but it has also been detected in some other cereals, including barley, wheat and broomcorn (Hussein and Brasel 2001). Cereals are contaminated during the cultivation period due to the

\footnotetext{
*Correspondence: dawei888888@163.com

1 Shandong Provincial Key Laboratory of Microbial Engineering, College of Biotechnology, Qilu University of Technology (Shandong Academy of Sciences), Jinan 250353, China

Full list of author information is available at the end of the article
}

Fusarium in soil. Contamination can also be caused by improper storage of cereals.

The economic losses to animal production and cultivation associated with ZEN contamination are enormous. The contamination also causes a series of food security problems. Though ZEN has a low acute toxicity, its negative impact on the reproduction of livestock is observed over time when ZEN contaminated fodder is fed to animals. ZEN can bind to estrogen receptors because its lactone ring is similar to the aromatic ring of estradiol (Fink-Gremmels and Malekinejad 2007). The issues of animal reproduction associated with estrogenic effects, such as low survival ratio of embryos, infertility and decreased litter weight, are induced by ZEN intake (Minervini and Dell'Aquila 2008). Pigs are more sensitive to ZEN than other animals such as rodents and ruminants. Besides having an adverse effect on the reproductive system, ZEN is also genotoxic and immunotoxic, and may lead to increased occurrence of hepatocellular and breast cancer (Ahamed et al. 2001; Ghedira-Chekir et al. 1998; Shier et al. 2001). 
Currently, there are three methods of reducing the amount of ZEN in cereals, which can be classified as physical, chemical and biological. Physical absorption is one of the most widely-used methods to tackle high concentrations of ZEN in feedstuffs. Chemical methods such as alkali and ozone treatments have been reported (Bennett et al. 1980; Karlovsky et al. 2016; Numanoglu et al. 2013). Biological treatment is a promising method of degradation of ZEN. Direct use of a microbial strain to degrade ZEN has been reported (Fu et al. 2016). It was demonstrated that Aspergillus niger FS10 was able to remove ZEN from medium and corn steep liquor (Sun et al. 2014). Three kinds of enzyme have been found to be able to degrade ZEN-laccase (EC 1.10.3.2), lactono hydrolase (E.C.3.1.1) and 2-Cys peroxiredoxin (EC 1.11.1.15) (Loi et al. 2017; Takahashi-Ando et al. 2002, 2005). Lactono hydrolase was one of the most studied ZEN degrading enzyme, such as ZHD101 (TakahashiAndo et al. 2002; Yang et al. 2017), ZHD (Peng et al. 2014; Xiang et al. 2016). Here, we expressed a zearalenone lactonase gene from Neurospora crassa in P. pastoris to yield an enzyme that can degrade ZEN.

\section{Materials and methods}

\section{Strains, plasmids and reagents}

ZEN was purchased from ROMER Labs (Austria), and it was dissolved in acetonitrile as a standard stock solution $(500 \mu \mathrm{g} / \mathrm{ml})$. Water was purified by Master-R-UVF (HHitech, China). Acetonitrile was chromatographically pure grade (Merck, Germany). P. pastoris GS115 (Invitrogen, USA) was used as the host strain for protein expression. The cloning plasmid pPIC9K (Invitrogen, USA) was used for heterologous expression of zearalenone lactonase in P. pastoris. Routine chemicals were of analytical grade (Sangon Biotech, China). Basal salts medium, buffered glycerol-complex medium (BMGY) and Yeast Extract Peptone Dextrose Medium (YPD) were prepared according to the instruction of Pichia Expression Kit and Pichia Fermentation Process Guidelines (Invitrogen, USA).

\section{Cloning and expression of zenc gene in P. pastoris}

The codons of the native zenc gene (GenBank ID: XM_958243.3) were optimized based on P. pastoris codon usage to obtain more effective protein expression. The optimized gene zenc (GenBank ID: MH780140) was synthesized with addition of EcoRI and NotI restriction sites at both ends by GenScript (Nanjing, China). The synthesized gene fragment was cloned into pPIC9K between the EcoRI and NotI restriction sites and fused in-frame with the $\alpha$-factor signal peptide. The resulting plasmid was linearized by SalI and then transformed into P. pastoris GS115 competent cells by electroporation.
The recombined plasmid was identified by restriction enzyme digestion and the gene was confirmed by PCR . The restriction sites were EcoRI and NotI respectively. The specific primers were ZENC-FP (5' TACCGGCAT AAGAGAGAAGG $3^{\prime}$ ) and ZENC-RP (5' TTAGTTTTC ACCAAGAAATGGCA $3^{\prime}$ ). The transformation mixtures were spread onto minimal dextrose plates to screen for positive recombinant cells expressing ZENC.

\section{Expression and purification of ZENC}

The recombinant $P$. pastoris strain was cultured in 250$\mathrm{ml}$ shaken flasks containing $25 \mathrm{ml}$ BMGY medium for $24 \mathrm{~h}\left(30{ }^{\circ} \mathrm{C}, 200 \mathrm{rpm}\right)$. Then, $1 \%$ methanol (v/v) was added to the culture every $24 \mathrm{~h}$ to induce expression of the target protein. The strain was induced for $72 \mathrm{~h}$.

For purification of protein, the cell culture supernatant was collected by centrifugation at $10,000 \mathrm{rpm}$ at $4{ }^{\circ} \mathrm{C}$ for 15 min. Protein was concentrated by adding Ammonium sulfate with a final saturation of $80 \%$. The protein precipitate was dissolved in $10 \mathrm{mM}$ Tris- $\mathrm{HCl}$ buffer $(\mathrm{pH}$ 7.5) and the solution was desalinated by ultracentrifugation using $10 \mathrm{kDa}$ filter units (Millipore, USA). The target protein was collected and applied to a HiTrap Q HP column (GE, USA), and eluted with a linear gradient from 0 to $1 \mathrm{M} \mathrm{NaCl}$. The purified protein was loaded onto polyacrylamide gel for SDS-PAGE analyzing, and a BCA Protein Assay Kit (Solarbio, China) was used to determine the concentration of protein.

\section{High-performance liquid chromatography (HPLC) analysis} The chromatographic system consisted of a Shimadzu LC-20AT pump and a Shimadzu RF-20A fluorescence detector. A Shim-Pack GIST C18 column $(4.6 \mathrm{~mm} \times 150 \mathrm{~mm}, 5 \mu \mathrm{m})$ was used for chromatographic separation. The mobile phase containing acetonitrilemethanol-water 46:8:46 (v/v/v) was used at a flow rate of $0.8 \mathrm{ml} / \mathrm{min}$. The column was kept at $30{ }^{\circ} \mathrm{C}$ and the injection volume was $20 \mu \mathrm{l}$. The excitation and emission wavelengths were 274 and $440 \mathrm{~nm}$, respectively. The concentration of ZEN was determined based on retention times and peak areas compared to ZEN standards dissolved in acetonitrile. A standard curve was generated for ZEN and the linear relation between peak area and concentration was in very good correlation.

\section{Degradation activity assay of ZEN}

The activity assay was performed at $45{ }^{\circ} \mathrm{C}$ and $\mathrm{pH}$ 8.0. The total reaction volume was $500 \mu \mathrm{l}$, which included $25 \mu \mathrm{l}$ enzyme solution, $455 \mu \mathrm{l}$ of $50 \mathrm{mM}$ Tris- $\mathrm{HCl}$ buffer $(\mathrm{pH} 8.0)$ and $20 \mu \mathrm{l} \mathrm{ZEN}$ standard solution $(500 \mu \mathrm{g} / \mathrm{ml})$. The reaction mixture was incubated at $45{ }^{\circ} \mathrm{C}$ for $5 \mathrm{~min}$ and then $500 \mu \mathrm{l}$ acetonitrile were added to terminate the reaction. The remaining ZEN concentration in the 
mixture was quantified by the Shimadzu Analytical HPLC system ("High-performance liquid chromatography (HPLC) analysis" section). One ZENC unit (U/ $\mathrm{ml}$ ) was defined as the amount of enzyme necessary to degrade $1 \mu \mathrm{g}$ ZEN in per minute at $45^{\circ} \mathrm{C}, \mathrm{pH}$ 8.0. ZEN degradation rate $(\%)=[10$ - remaining ZEN concentration $(\mu \mathrm{g} / \mathrm{ml})] / 10 \times 100 \%$. Results represent the averages of three independent experiments.

\section{Characterization and kinetic analysis of enzyme}

To determine the optimal $\mathrm{pH}$ of ZENC activity, incubation was performed in $50 \mathrm{mM} \mathrm{Na2HPO} 4$-citric acid buffer (pH 2.2-7.5), $50 \mathrm{mM}$ Tris- $\mathrm{HCl}(\mathrm{pH} 7.5-9.0)$ and $50 \mathrm{mM}$ borate buffer ( $\mathrm{pH} \mathrm{10}$ ) at $37{ }^{\circ} \mathrm{C}$ for $5 \mathrm{~min}$. The $\mathrm{pH}$ stability of ZENC was estimated by determining the residual activity in standard conditions $\left(\mathrm{pH} 8.0,45^{\circ} \mathrm{C}\right.$, $5 \mathrm{~min}$ ) after preincubation of enzyme solution in buffers at $\mathrm{pH} 2.2-10$ at $37^{\circ} \mathrm{C}$ for $1 \mathrm{~h}$ without substrate. The activity of ZENC without incubation was considered $100 \%$. The optimal reaction temperature was determined by performing the reaction at $20-60{ }^{\circ} \mathrm{C}$ in $50 \mathrm{mM}$ Tris$\mathrm{HCl}(\mathrm{pH} \mathrm{8.0)}$ for $5 \mathrm{~min}$. The reaction was terminated by adding $500 \mu \mathrm{l}$ acetonitrile and reaction mixture $(20 \mu \mathrm{l})$ was analyzed by HPLC. The thermostability of ZENC was explored by measuring the residual enzymatic activity after incubating the enzyme in $50 \mathrm{mM}$ Tris $-\mathrm{HCl}(\mathrm{pH}$ 8.0) at temperature ranging from 20 to $80{ }^{\circ} \mathrm{C}$ without substrate for different periods of time. The enzyme stability at $37^{\circ} \mathrm{C}, \mathrm{pH} 8.0$ was tested particularly. The enzyme activity was measured after ZENC was stored at $37^{\circ} \mathrm{C}$, $\mathrm{pH} 8.0$ for different time. The enzymes activity of $0 \mathrm{~h}$ incubation was set as $100 \%$ activity. The effects of different metal ions and chemicals on the activity of ZENC were measured by adding $5 \mathrm{mM}$ various metal salts $\left(\mathrm{NaCl}, \mathrm{CaCl}, \mathrm{MnSO}_{4}, \mathrm{MgSO}_{4}, \mathrm{CuSO}_{4}\right.$ ) and regents (SDS, EDTA) to assay system ("Degradation activity assay of ZEN" section). 5, 10, $15 \mathrm{mM} \mathrm{ZnSO}_{4}$ was added to assay system separately. The system without any additive was used as a control.

Kinetic analysis was performed in $50 \mathrm{mM}$ Tris- $\mathrm{HCl}$ buffer ( $\mathrm{pH}$ 8.0) at ZEN concentrations ranging from 2 to $220 \mathrm{mM}$ at $45{ }^{\circ} \mathrm{C}$ for $3 \mathrm{~min}$. Kinetic parameters $\mathrm{K}_{\mathrm{m}}$ and $\mathrm{V}_{\max }$ were determined using the Hill equation: $\mathrm{v}=\mathrm{V}_{\max } /$ $\left[1+\left(K_{m} / C\right) n\right]$, where $v$ is the enzyme velocity, $C$ is the substrate concentration, $K_{m}$ is the substrate concentration at the half-maximum velocity, $\mathrm{n}$ is the Hill coefficient $(\mathrm{n}=1)$, and $\mathrm{V}_{\max }$ is the maximal velocity. The data were fitted to a nonlinear curve using Origin Pro 8 software (OriginLab, USA).

\section{Expression of ZENC in a 30-I fermenter}

To scale up ZENC production, high cell-density fermentation was performed according to the Pichia fermentation process guidelines (Invitrogen). A colony of the ZENC-producing strain was inoculated into $100 \mathrm{ml}$ YPD medium and incubated in rotary shaker of $200 \mathrm{rpm}$ at $30{ }^{\circ} \mathrm{C}$ for $24 \mathrm{~h}$ as the first seed culture. The second seed culture was prepared by transferring the first seed culture into $900 \mathrm{ml}$ YPD medium and grown for $10 \mathrm{~h}$ at $30{ }^{\circ} \mathrm{C}$. The second seed was transferred into the $30-1$ fermenter containing $19 \mathrm{l}$ BMGY medium with $10 \mathrm{ml} / \mathrm{l}$ PTM1 solution. The system was maintained $30{ }^{\circ} \mathrm{C}, \mathrm{pH}$ 6.0, with ammonia. The carbon source was exhausted approximately after $18 \mathrm{~h}$ and DO then rapidly increased to $70 \%, 12 \mathrm{ml} / \mathrm{l}$ PTM1 solution with $50 \%$ glycerol (w/v) was fed into the fermenter; the DO level was maintained at $20-30 \%$ by controlling the feeding rate. After the wet weight of cells reached $200 \mathrm{~g} / \mathrm{l}$, pure methanol feeding (instead of glycerol feeding) commenced to induce expression of the target protein. Cell culture was collected every $12 \mathrm{~h}$ to determine the ZENC activity.

\section{Application of ZENC on degradation of ZEN in distillers dried grains with solubles (DDGS), maize by-products and corn bran}

DDGS, maize by-products and corn bran (25 g) were respectively mixed with $20 \mathrm{ml}$ crude enzyme $(40.0 \mathrm{U} /$ $\mathrm{ml}, \mathrm{pH} 6.2$ ) and adjusted to $\mathrm{pH} 8.0$ by adding $\mathrm{NaOH}$ dissolved in $5 \mathrm{ml}$ water. In the control, sample $(25 \mathrm{~g})$ was mixed with $20 \mathrm{ml}$ inactive crude enzyme (inactivated by boiling-heat for $10 \mathrm{~min}, \mathrm{pH} 6.2$ ) and adjusted to $\mathrm{pH}$ 8.0 by adding $5 \mathrm{ml}$ of $5 \mathrm{M} \mathrm{NaOH}$ solution. The mixture was incubated at $37{ }^{\circ} \mathrm{C}$ for different periods of time. After incubation, the mixture was heated in an oven at $75^{\circ} \mathrm{C}$ and crushed. Crushed mixture $(20 \mathrm{~g})$ and $100 \mathrm{ml}$ acetonitrile were added to extract any remaining ZEN and blended in an incubating shaker (ZHCHENG Inc., Shanghai, China) for $20 \mathrm{~min}$ at room temperature. The extract was filtered through glass microfiber filters (934$\mathrm{AH}$, Whatman). This filtrate $(10 \mathrm{ml})$ was diluted with $40 \mathrm{ml} 0.01 \mathrm{M}$ PBST solution $(8 \mathrm{~g} \mathrm{NaCl}, 0.2 \mathrm{~g} \mathrm{KCl}, 0.2 \mathrm{~g}$ $\mathrm{KH}_{2} \mathrm{PO}_{4}, 1.16 \mathrm{~g} \mathrm{Na}_{2} \mathrm{HPO}_{4} \cdot 12 \mathrm{H}_{2} \mathrm{O}$ and $2 \mathrm{ml}$ Tween-20 dissolved in water to total volume of $1 \mathrm{l}$ ). The dilution $(25 \mathrm{ml})$ was washed using a Zearalenone Immunoaffinity Column (Huaan Magnech Bio-Tech, China) according to the manufacturer's recommendations, and the ZEN concentration was quantified using the HPLC system ("Highperformance liquid chromatography (HPLC) analysis" section). ZEN concentration $(\mu \mathrm{g} / \mathrm{kg})=$ remaining $\mathrm{ZEN}$ concentration $(\mu \mathrm{g} / \mathrm{ml})$ demonstrated by HPLC $\times 1000$.

\section{Results}

Construction of expression plasmids

Total of 196 codons of ZENC were optimized according to the codon usage of $P$. pastoris. After optimization we reduced the GC content from 57.71 to $44.81 \%$ 
and increased the codon adaptation index from 0.58 to 0.95 . The gene fragment was synthesized and successfully cloned into pPIC9K, fused in-frame with the $\alpha$-factor signal peptide. Based on amino acid analysis, the deduced mature ZENC protein contained 296 residues. The deduced amino acid sequence of ZENC was analyzed by using BLAST server (https://www.ncbi.nlm.nih. gov/BLAST) and shows its highest identity (97\%) with a hypothetical protein from $N$. tetrasperma, and identity of $29 \%$ with an experimentally-verified zearalenone hydrolase (ZHD101) from Clonostachys rosea. The result of amino acid sequence analysis also revealed that ZENC have a significant level of similarity ( $23 \%$ of identity) to a 2-(acetamidomethylene) succinate hydrolase (Accession Number: WP_010914326.1) from Mesorhizobium japonicum. The conserved domain search showed that these two enzymes have a common structural feature named $\alpha / \beta$ hydrolase fold. Serine hydrolase family was characterized by having a catalytic triad. The sequence alignment demonstrated that ZENC has a catalytic triad consisting of Ser ${ }^{117}$, Asp ${ }^{141}$ and His ${ }^{274}$ (Fig. 1c, boxed residues), so we proposed that ZENC belong to the serine hydrolase family.

\section{Expression and purification of ZENC}

The target protein ZENC was successfully expressed and secreted by $P$. pastoris. The supernatants of transformant cultures of recombinant $P$. pastoris and of $P$. pastoris were analyzed by SDS-PAGE (not shown). The enzyme activity of the transformant cultures was $40.0 \mathrm{U} / \mathrm{ml}$ after methanol induction for $72 \mathrm{~h}$ in shaken flasks. ZENC from the supernatant was purified and the specific activity of the purified enzyme was $530.4 \mathrm{U} / \mathrm{mg}$. The molecular mass of the purified enzyme was found to be about $29 \mathrm{kDa}$ by SDS-PAGE.

\section{Characterization of recombinant protein}

Degradation activity assay of ZEN showed that $99.75 \%$ of the ZEN $(20 \mu \mathrm{g} / \mathrm{ml})$ was degraded by ZENC in $15 \mathrm{~min}$. For purifying protein, the recombinant strain was cultured in shaking flasks and induced with methanol for 3 days. Then the supernatant was precipitated by adding ammonium sulfate, desalinated by ultrafiltration, and purified by HiTrap Q HP column chromatography. The purified recombinant protein was analyzed by SDS-PAGE.

Recombinant protein was tested with ZEN at various temperature and $\mathrm{pH}$. The optimal temperature and $\mathrm{pH}$ for enzyme activity were $45^{\circ} \mathrm{C}$ and 8.0 , respectively (Fig. 2). The thermostability of ZENC was good at the temperature ranging from 20 to $50{ }^{\circ} \mathrm{C}$ and the activity of enzyme was almost lost at $60{ }^{\circ} \mathrm{C}$ for $1 \mathrm{~min}$. ZENC was stable at $\mathrm{pH}$ range from 6.0 to 9.0, and the highest $\mathrm{pH}$ stability was achieved at $\mathrm{pH}$ 6.0. The stability of ZENC at $37^{\circ} \mathrm{C}$ was shown in Table 1 . The kinetic parameters of ZENC with ZEN were determined at $\mathrm{pH} 8.0$ and $45^{\circ} \mathrm{C}$. $\mathrm{K}_{\mathrm{m}}$ was $38.63 \pm 5.868 \mu \mathrm{M}$, and $\mathrm{V}_{\max }$ was $23.8 \mu \mathrm{M} / \mathrm{s} / \mathrm{mg}$. The effect of different metal ions or chemical reagents on the activity of purified ZENC was determined at a final concentration of $5 \mathrm{mM}$ (Table 2). $\mathrm{Mg}^{2+}, \mathrm{Na}^{+}$and $\mathrm{Ca}^{2+}$ had no effects on the enzyme activity. $\mathrm{Mn}^{2+}$ inhibited the enzyme activity partially. The enzyme activity was almost completely lost with the presence of $\mathrm{Cu}^{2+}, \mathrm{SDS}$ and EDTA. A decline trend of enzyme activity was observed as the concentration of $\mathrm{Zn}^{2+}$ increased from 5 to $15 \mathrm{mM}$.

\section{Expression of ZENC in a 30-I fermenter}

A high-density cell fermentation of $P$. pastoris was carried out in a 30-1 fermenter for high expression of ZENC. The methanol induction time was up to $100 \mathrm{~h}$ and fermentation broth collected every $12 \mathrm{~h}$ were analyzed (Fig. 3 ). The target protein was not detected before methanol was fed into the fermenter. Enzyme activity was analyzed by HPLC. The activity of ZENC reached its highest level after $72 \mathrm{~h}$ of induction: the wet weight of cells reached $485 \mathrm{~g} / \mathrm{l}$ and the maximum enzyme activity was $290.6 \mathrm{U} /$ $\mathrm{ml}$. The enzyme activity in the fermenter was 7.27 -fold that in shaken flask fermentation $(40.0 \mathrm{U} / \mathrm{ml})$.

\section{Application of ZENC on degradation of ZEN in DDGS, maize by-products and corn bran}

We added recombinant ZENC to ZEN-containing DDGS, maize by-products and corn bran. All samples were processed at $37{ }^{\circ} \mathrm{C}, \mathrm{pH}$ 8.0. The DDGS sample containing ZEN about $316 \mu \mathrm{g} / \mathrm{kg}$ was treated for $24 \mathrm{~h}$, and the residual ZEN concentration was reduced to the level of $92 \mu \mathrm{g} / \mathrm{kg}$. The ZEN concentration did not decrease further even after the degradation was performed for $48 \mathrm{~h}$. Maize by-products containing ZEN of $3732 \mu \mathrm{g} / \mathrm{kg}$ were treated under the same conditions and the remaining concentration of ZEN was decreased to $416 \mu \mathrm{g} / \mathrm{kg}$ after degradation for $48 \mathrm{~h}$; the level of degradation was thus $88.9 \%$. For corn bran, $88.0 \%$ of the ZEN (initial concentration $2142 \mu \mathrm{g} / \mathrm{kg}$ ) was removed after $3 \mathrm{~h}$ of degradation, and the ZEN concentration was down to $113 \mu \mathrm{g} / \mathrm{kg}$ after $6 \mathrm{~h}$ of degradation. The degradation level of ZEN in corn bran was $94.7 \%$ (Fig. 4).

\section{Discussion}

Methods of degrading ZEN in cereal have attracted increasing attention in the past two decades (Higa et al. 2003; McCormick 2013). Currently, most biodegradation methods of ZEN applied in practice involve adding a microbial strain that can metabolize ZEN to a nontoxic compound (Fu et al. 2016). Cell-free biodegradation systems have seldom been used to deal with ZEN 

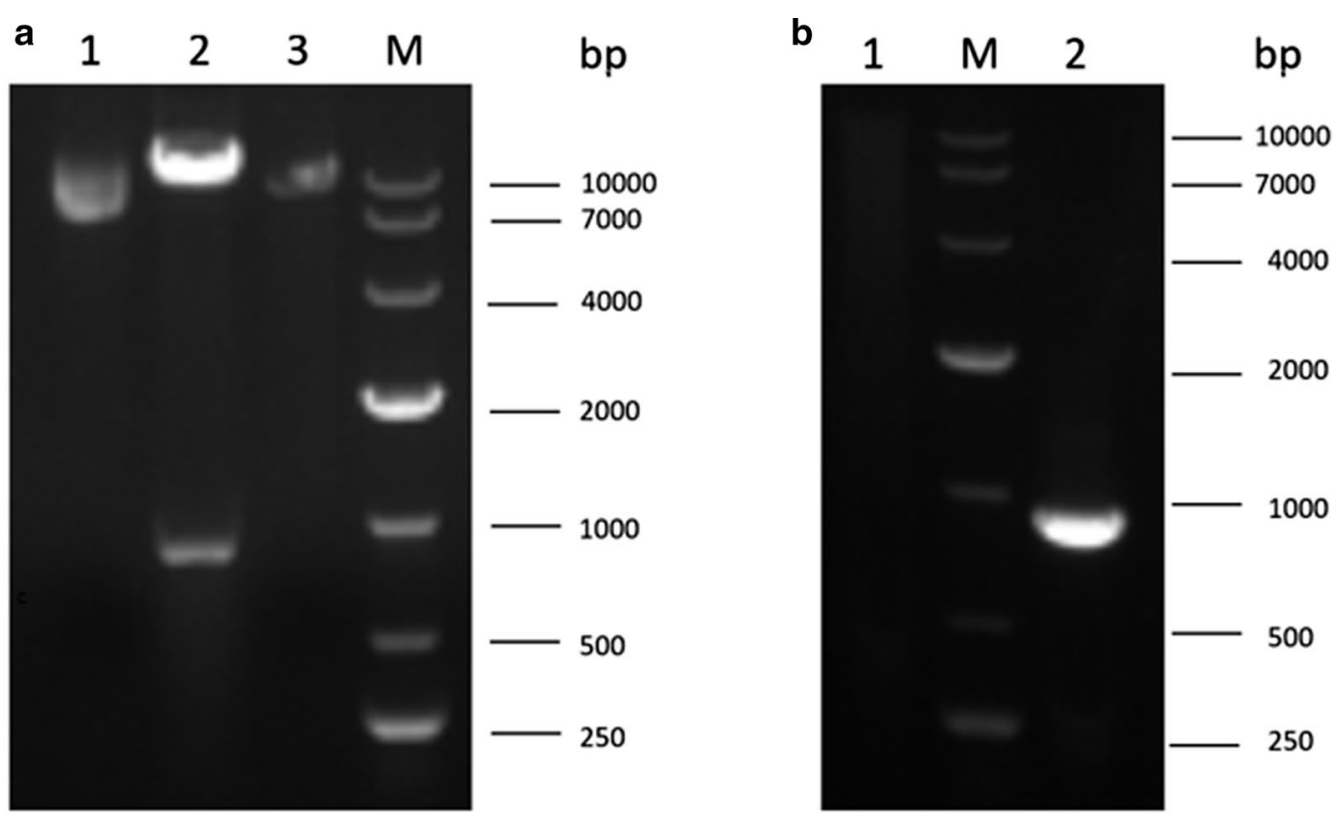

C

1) PTVLLSNSLASQYHFWDHIVERLHNAGYRVLRYDHPGHGASGVPDNLSSTTFASLAEDVY 84

2) PLMLFFHGITSNSAVFEPLMIRLSDR-FTTIAVDQRGHGLSDKPE--TGYEANDYADDIA 89

1) ALLTSPDVATAFHGHHSPDAAFTPSLHAWIGVSMGAALGVVFSSRYPGVVQRLVICDTIS 144

2) GL-----IRTLARGHA---------ILVGHSLGARNSVTAAAKYPDLVRSVVAIDFTP 133

1) ASPKNAGVSDALGPRVAAAREHGSMEKAVVETMDRWFGQDWIKANPAEAERVHLLMKQTS 204

2) YIETEA--LDALEARVNA----GSQLFEDIKAVEAYLAGRYPNI-PADAIRIRAESGYQP 186

1) LDGFETCIAA---------LRSDSFDIRPLISGLGNCVQRVLFVVGEKDADLPEKMKEQ 254

2) VDGGLRPLASSAAMAQTARGLRSD-----LVPAYRDVTKPVLIVRGESS----KLVSAA 236

1) RDACPENLKAELK--VIPNAGHVSFIDGKEDFLKAVMPFL 292

2) ALAKTSRLRPDLPVVVVPGGADHYNEVSPEITLKAIITNFI 276

Fig. 1 a Electrophoresis analysis of expression plasmid. lane M: marker; lane 1: recombined plasmid; lane 2: recombined plasmid was digested by ECoRI and Notl; lane 3: pPIC9K was digested by EcoRI and Notl. b Electrophoresis analysis of PCR. lane M: marker; lane 1: PCR of P. pastoris; lane 2: PCR of recombinant P. pastoris. c Alignment of the deduced amino acid sequence of ZENC (1, upper line) with 2-(acetamidomethylene) succinate hydrolase from Mesorhizobium japonicum (2, lower line). Identical (.) are shown. Residues that comprise the catalytic triad of a serine hydrolase family are boxed

contamination. Extensive work is required to screen for strains having a particular function, and genetically modified organisms are strictly regulated. All these factors increase the practical cost, so enzymatic degradation of ZEN is considered as a promising method to solve problems of ZEN contamination.

Expression of proteins in eukaryotic expression systems is widely used. P. pastoris shows high level protein expression which can be induced by methanol (Love et al. 2017). Its protein processing system was suitable for protein expression such as signal peptide cleavage, protein folding, post-translational modifications inside the cell and the ability of secreting protein into the medium with normal function (Jia et al. 2013; Liu et al. 2013). We employed $P$. pastoris as a secretory expression system to express the ZEN degrading enzyme $N$. crassa ZENC. From SDS-PAGE (Fig. 3), it can be clearly seen that ZENC was expressed at a high level in the supernatant of 

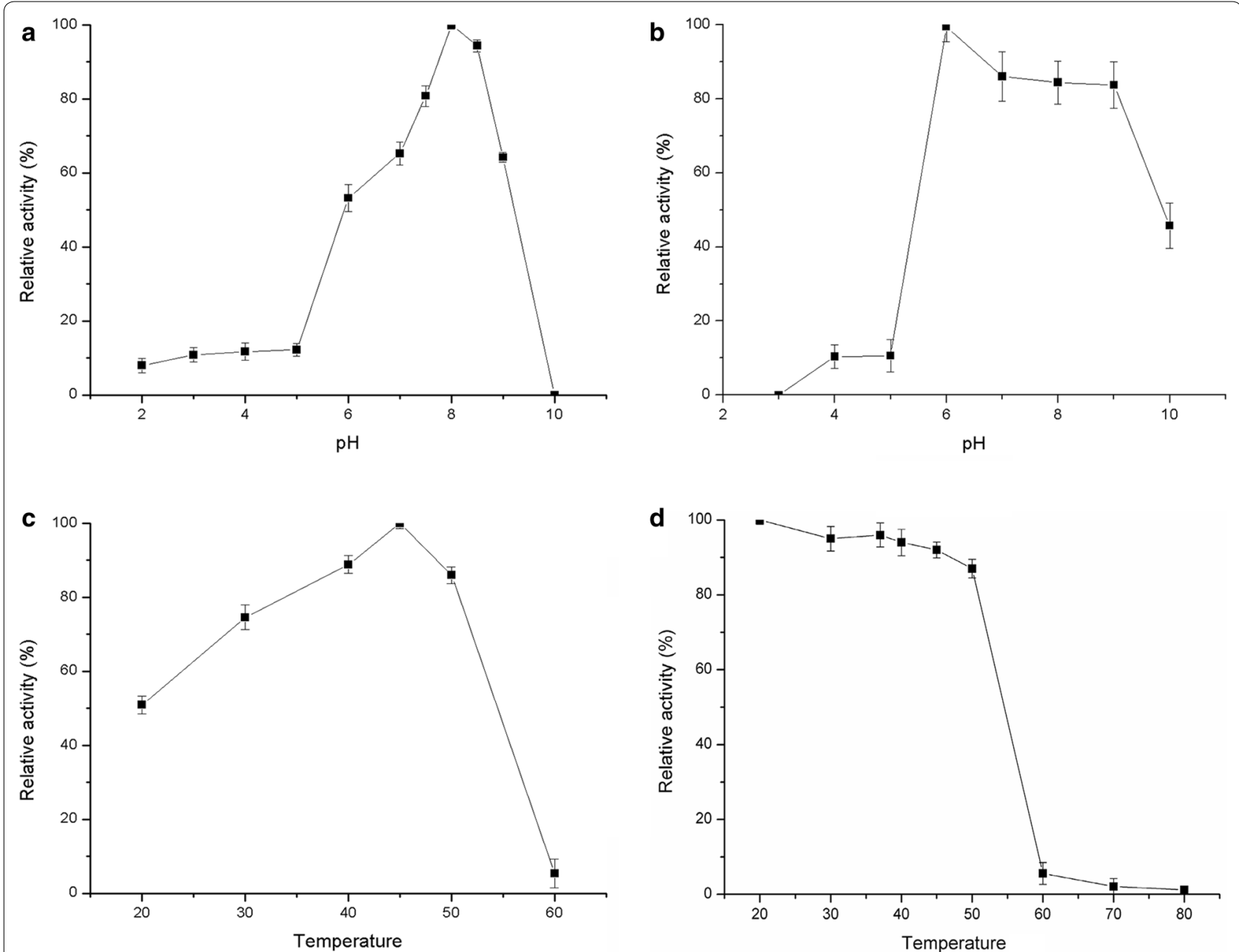

Fig. 2 Effect of temperature and pH on the enzyme activity of recombinant ZENC. a Effect of pH on the enzyme activity. $\mathbf{b}$ pH stability of recombinant enzyme. $\mathbf{c}$ Effect of temperature on the enzyme activity. $\mathbf{d}$ Thermostability of recombinant enzyme. Error bars represent the standard devision of values and every case was carried out three experiments

Table 1 Stability of ZENC at $37^{\circ} \mathrm{C}$

\begin{tabular}{ll}
\hline Time (h) & Relative activity (\%)* \\
\hline 0 & 100 \\
6 & $79.5 \pm 2.69$ \\
12 & $66.7 \pm 3.01$ \\
24 & $40.3 \pm 2.24$ \\
48 & $9.1 \pm 1.38$ \\
\hline
\end{tabular}

* Values represent mean $\pm S D(n=3)$ relative to $0 h$ sample

P. pastoris cultures and this would be beneficial for separating the target protein.

The activity of the recombinant protein reached $40.0 \mathrm{U} /$ $\mathrm{ml}$ in shaken flask fermentation. Determined by HPLC, $82 \%$ of $10 \mu \mathrm{g}$ ZEN was degraded by ZENC within $10 \mathrm{~min}$ and $99 \%$ of $10 \mu \mathrm{g} Z \mathrm{ZEN}$ was degraded within $15 \mathrm{~min}$, while it took $30 \mathrm{~min}$ for ZHD to degrade the same amount of ZEN (Xiang et al. 2016). To our knowledge, the activity of the recombinant ZEN degrading enzyme reported here is higher than those of all other ZEN degrading enzymes reported previously. We determined the $\mathrm{K}_{\mathrm{m}}$ and $\mathrm{V}_{\max }$ values of this recombinant enzyme toward $\mathrm{ZEN}$ at $\mathrm{pH}$ 8.0, which were $38.63 \pm 5.868 \mu \mathrm{M}$ and $23.8 \mu \mathrm{M} / \mathrm{s} / \mathrm{mg}$, respectively (enzymes with low $\mathrm{K}_{\mathrm{m}}$ having have high affinity for the substrate) (Johnson 2013; Kang et al. 2008; Seibert and Tracy 2014). The optimal temperature and $\mathrm{pH}$ of ZENC activity were $45^{\circ} \mathrm{C}$ and 8.0 respectively. A Zearalenone lactonohydrolase ZHD101 from Clonostachys rosea has a lower $\mathrm{K}_{\mathrm{m}}(8.5 \mu \mathrm{M})$ toward $\mathrm{ZEN}$ at $\mathrm{pH} 8.5$ and the optimal pH of ZHD101 expressed in Escherichia coli was 10.5 (Takahashi-Ando et al. 2004). The enzyme activity of ZENC (relative to maximum activity) was over $85 \%$ 
Table 2 Effect of ions and chemicals on ZENC

\begin{tabular}{llc}
\hline Chemicals & Concentration $(\mathbf{m M})$ & Relative activity (\%) \\
\hline $\mathrm{Zn}^{2+}$ & 5 & $77.3 \pm 2.51$ \\
$\mathrm{Zn}^{2+}$ & 10 & $36.4 \pm 2.64$ \\
$\mathrm{Zn}^{2+}$ & 15 & $17.8 \pm 2.96$ \\
$\mathrm{Cu}^{2+}$ & 5 & $1.6 \pm 0.90$ \\
$\mathrm{Mn}^{2+}$ & 5 & $44.9 \pm 1.08$ \\
$\mathrm{Mg}^{2+}$ & 5 & $103.2 \pm 1.24$ \\
$\mathrm{Na}^{+}$ & 5 & $99.6 \pm 0.88$ \\
$\mathrm{Ca}^{2+}$ & 5 & $94.8 \pm 1.37$ \\
$\mathrm{SDS}$ & 5 & $3.1 \pm 1.16$ \\
EDTA & 5 & $9.211 \pm 2.84$ \\
\hline
\end{tabular}

* Values represent mean $\pm S D(n=3)$ relative to untreated control samples

at $40-50{ }^{\circ} \mathrm{C}$, while ZHD101 had maximal activity at 37 to $45{ }^{\circ} \mathrm{C}$, so ZENC is more thermostable. The enzyme activity of ZENC was sharply and irreversibly reduced at $\mathrm{pH}$ values below 5 or at temperature of more than $60^{\circ} \mathrm{C}$ (Table 3). Various research indicates that the ratio of positively and negatively charged residues on the surface of a protein may be related to its $\mathrm{pH}$ adaptation (Mamo et al. 2009), and that the surface amino acids of a protein are correlated with its adaption to extreme temperatures (Feller 2003; Sterner and Liebl 2001). The predicted pI of ZENC was 5.71 determined by ExPASy (https:// web.expasy.org/protparam/) and the enzyme activity of ZENC was significantly decreased below $\mathrm{pH}$ 6.0. We suggest that a negatively charged surface of the protein has an advantageous effect on the enzyme activity of ZENC.
To our knowledge, this is first report that ZENC has been expressed in $P$. pastoris using high-density fermentation and applied to reduce the amount of ZEN from ZEN-containing materials such as maize and its by-products. We explored the effect of ZEN degradation by adding recombinant enzyme into DDGS, maize by-products and corn bran. High concentrations of ZEN are commonly reported in maize ingredients, and this limits their practical use. After the pretreatment with ZENC, the final ZEN concentrations in DDGS, maize byproducts and corn bran were $92 \mu \mathrm{g} / \mathrm{kg}, 416 \mu \mathrm{g} / \mathrm{kg}$ and $113 \mu \mathrm{g} / \mathrm{kg}$, respectively. The maize was contaminated by the Fusarium existed in soil during the growing process, and the most of zearalenone was distributed on the surface of the corn. The degrading effect of corn bran was better than that of DDGS or maize by-products. We proposed that the high concentration of zearalenone and the simple ingredient contribute to the degrading effect of corn bran. The DDGS and maize by-products are products produced from maize, and the ingredients of DDGS and maize by-products are complex. These complex ingredient may coating the corn bran then inhibiting ZENC to reach the zearalenone, so the degrading performance of DDGS or maize by-products was not as good as that of corn bran. The maximum limits for ZEN in food and feeds differ in various countries. For example, the limit is $100 \mu \mathrm{g} / \mathrm{kg}$ for cereals and derived products in Italy, $1000 \mu \mathrm{g} / \mathrm{kg}$ for compound feeds in Japan, and $50 \mu \mathrm{g} / \mathrm{kg}$ for cereal products in France (Zinedine et al. 2007). Our results demonstrate that ZENC is a promising enzyme used as an additive in the food and animal
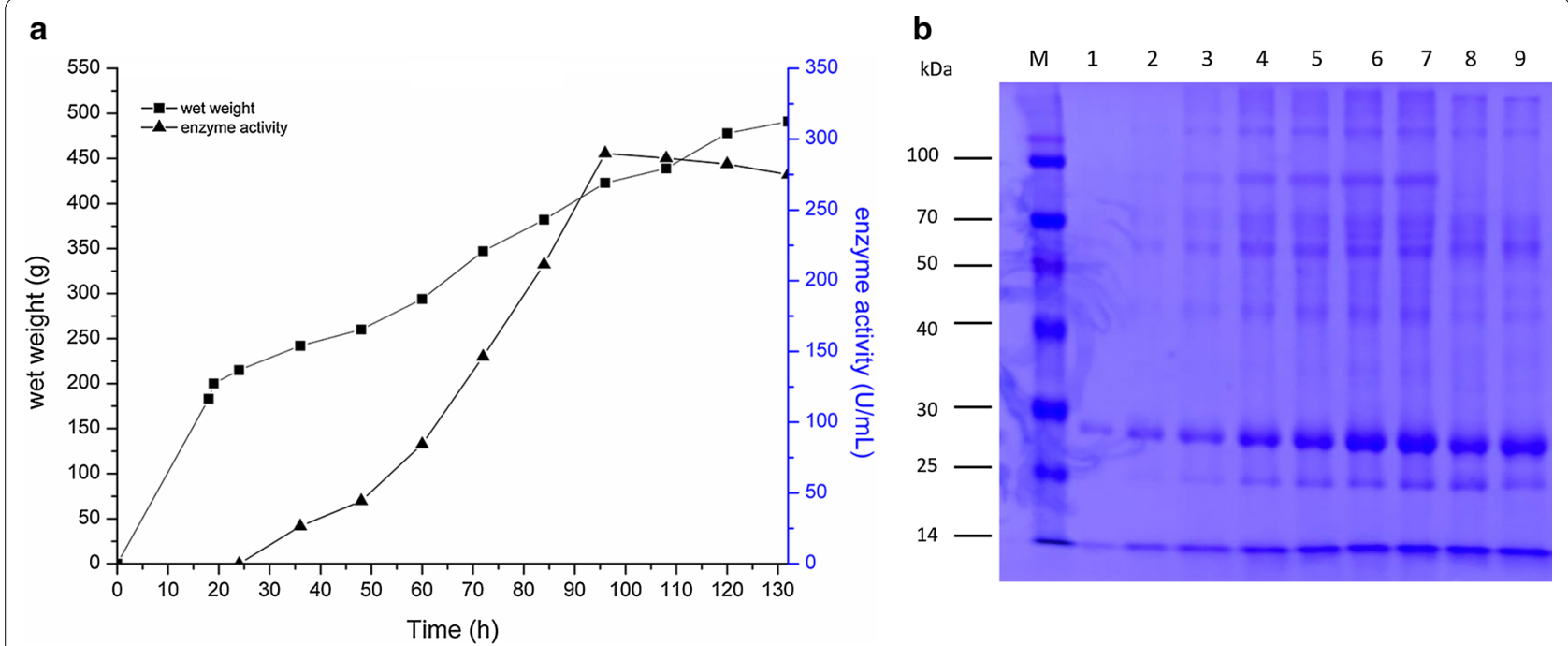

Fig. 3 High-density fermentation of recombinant P. pastoris expressing ZENC in a 30-I fermenter. a Wet weight of cells and enzyme activity. $\mathbf{b}$ SDS-PAGE analysis of culture supernatant from the 30-I fermenter at different periods of incubation time; Lanes 1-9, sample supernatants from culture induced with methanol for $12,24,36,48,60,72,84,96$ and 108 h, respectively 

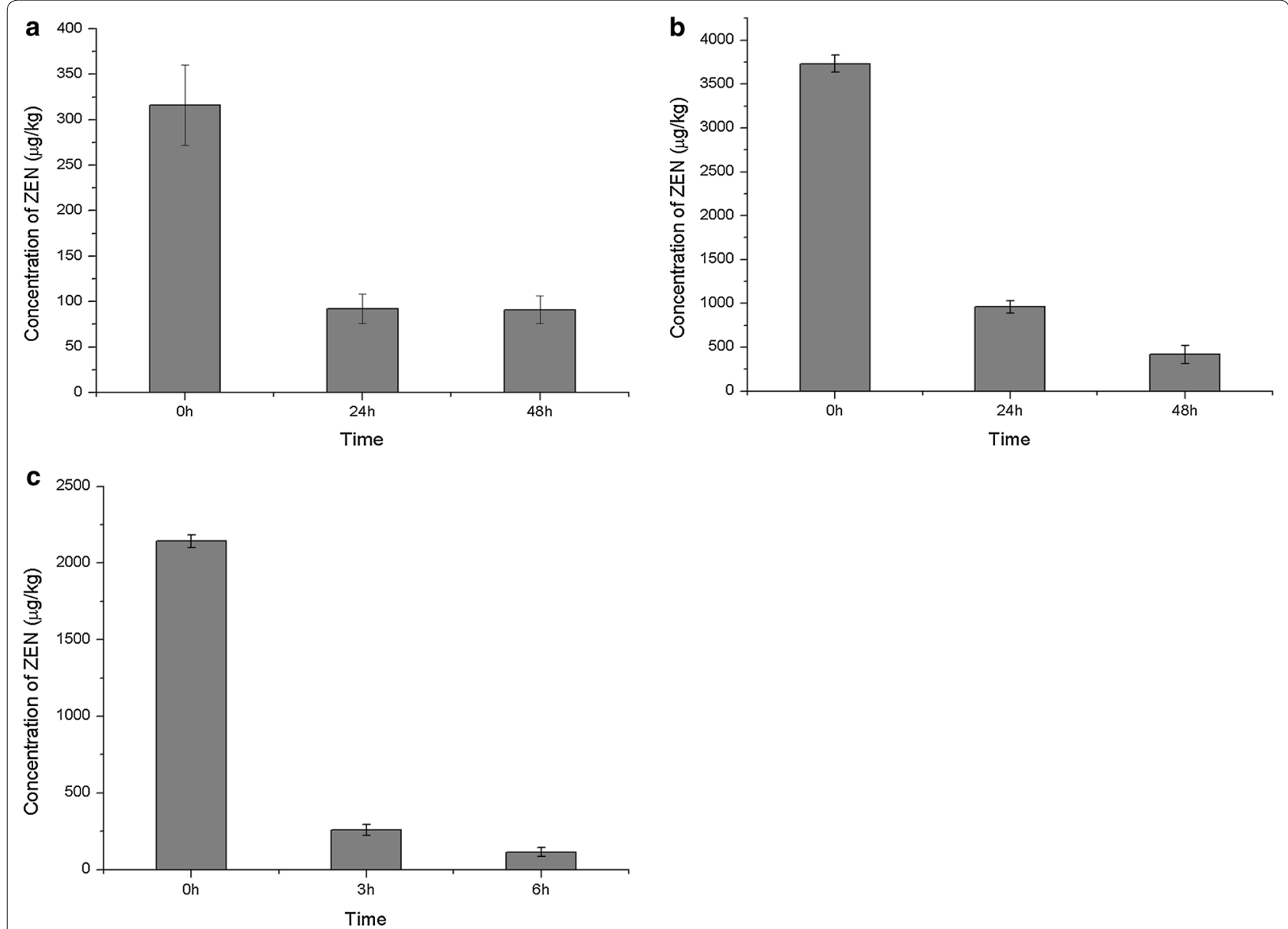

Fig. 4 Zearalenone (ZEN) degradation in different substrates on addition of ZENC. a ZEN degradation in DDGS. b ZEN degradation in maize by-products. c ZEN degradation in corn bran

Table 3 Comparison of this work with literature reports on zearalenone degrading enzymes

\begin{tabular}{|c|c|c|c|}
\hline Enzyme name & Organism & Degrading properties & Reference \\
\hline Laccase & Streptomyces coelicolor & $\begin{array}{l}\text { Incubation at } \mathrm{pH} 4.5,37^{\circ} \mathrm{C} \text { for } 24 \mathrm{~h}, 100 \% \text { of ZEN }\left(6 \times 10^{-4} \mu \mathrm{g} / \mathrm{ml}\right) \text { was } \\
\text { degraded }\end{array}$ & Novozymes A/S (2009) \\
\hline Laccase & Trametes versicolor & Incubation at $\mathrm{pH} 5.2,30^{\circ} \mathrm{C}$ for $4 \mathrm{~h}, 58 \%$ of ZEN $(9.36 \mu \mathrm{g} / \mathrm{ml})$ was degraded & Novozymes A/S (2009) \\
\hline 2cys-peroxiredoxin & Acinetobacter sp. SM04 & $\begin{array}{l}\text { Incubation with } \mathrm{H}_{2} \mathrm{O}_{2}(20 \mathrm{mM}) \text { at } \mathrm{pH} 9.0,30^{\circ} \mathrm{C} \text { for } 4 \mathrm{~h}, 95 \% \text { of ZEN }(20 \mu \mathrm{g} / \\
\text { ml) was degraded }\end{array}$ & Yu et al. (2012) \\
\hline \multirow[t]{2}{*}{ Lactonehydrolase } & Clonostachys rosea & Incubation at $\mathrm{pH} 9,37^{\circ} \mathrm{C}$ for $30 \mathrm{~min}, 100 \%$ of ZEN $(20 \mu \mathrm{g} / \mathrm{ml})$ was degraded & Xiang et al. (2016) \\
\hline & & $\begin{array}{l}\text { Optimal temperature was } 37 \text { to } 45^{\circ} \mathrm{C} \text {; optimal pH was } 10.5 \text {; inactivated at } \\
50^{\circ} \mathrm{C} \text { or at } \mathrm{pH} 4.5\end{array}$ & Takahashi-Ando et al. (2004) \\
\hline \multirow[t]{2}{*}{ Lactonehydrolase } & Neurospora crassa & $\begin{array}{l}\text { Incubation at } \mathrm{pH} 8.0,45^{\circ} \mathrm{Cfor} 15 \mathrm{~min}, 99.75 \% \text { of ZEN }(20 \mu \mathrm{g} / \mathrm{ml}) \text { was } \\
\text { degraded }\end{array}$ & \\
\hline & & $\begin{array}{l}\text { Optimal temperature was } 45^{\circ} \mathrm{C} \text {; optimal pH was } 8.0 \text {; inactivated at } 60^{\circ} \mathrm{C} \text { or } \\
\text { at pH } 5\end{array}$ & This work \\
\hline
\end{tabular}

feed industries, especially in corn processing. P. pastoris is suitable for expressing ZENC, which has promising $\mathrm{pH}$ and thermostability for industrial application.

\section{Abbreviations}

ZEN: zearalenone; HPLC: high-performance liquid chromatography; DDGS: distillers dried grains with solubles; YPD: yeast extract peptone dextrose medium: BMGY: buffered glycerol-complex medium. 


\section{Authors' contributions}

DZ and ZX conceived and designed experiments. KB and ZW performed the experiments. KB analyzed the data. KB written the research paper with help from DZ and ZX. All authors read and approved the final manuscript.

\section{Author details}

1 Shandong Provincial Key Laboratory of Microbial Engineering, College of Biotechnology, Qilu University of Technology (Shandong Academy of Sciences), Jinan 250353, China. ${ }^{2}$ Qingdao Red Cherry Biotech Ltd, Qingdao 266111, China.

\section{Acknowledgements}

We thank Liwen Bianji, Edanz Group China (http://www.liwenbianji.cn/ac), for editing the English text of a draft of this manuscript.

\section{Competing interests}

The authors declare that they have no competing interests.

\section{Availability of data and materials}

The dataset supporting the conclusions of this article is included within the article. All data are fully available without restriction.

\section{Consent for publication}

Not applicable.

\section{Ethics approval and consent to participate}

Not applicable.

\section{Funding}

This work was supported by the National Key Research and Development Program of China (Project No. 2017YFC1600900).

\section{Publisher's Note}

Springer Nature remains neutral with regard to jurisdictional claims in published maps and institutional affiliations.

Received: 29 July 2018 Accepted: 15 December 2018

Published online: 20 December 2018

\section{References}

Ahamed S, Foster JS, Bukovsky A, Wimalasena J (2001) Signal transduction through the Ras/Erk pathway is essential for the mycoestrogen zearalenone-induced cell-cycle progression in MCF-7 cells. Mol Carcinog 30(2):88-98

Bennett JW, Klich M (2003) Mycotoxins. Clin Microbiol Rev 16(3):497-516

Bennett GA, Shotwell OL, Hesseltine CW (1980) Destruction of zearalenone in contaminated corn. J Am Oil Chem Soc 57(8):245-247

Feller G (2003) Molecular adaptations to cold in psychrophilic enzymes. Cell Mol Life Sci 60(4):648-662

Fink-Gremmels J, Malekinejad H (2007) Clinical effects and biochemical mechanisms associated with exposure to the mycoestrogen zearalenone. Anim Feed Sci Technol 137(3):326-341

Fu G, Ma J, Wang L, Yang X, Liu J, Zhao X (2016) Effect of degradation of zearalenone-contaminated feed by Bacillus licheniformis CK1 on postweaning female piglets. Toxins. https://doi.org/10.3390/toxins8100300

Ghedira-Chekir L, Maaroufi K, Zakhama A, Ellouz F, Dhouib S, Creppy EE, Bacha $H$ (1998) Induction of a SOS repair system in lysogenic bacteria by zearalenone and its prevention by vitamin E. Chem Biol Interact 113(1):15-25

Higa A, Kimura M, Mimori K, Ochiai-Fukuda T, Tokai T, Takahashi-Ando N, Nishiuchi T, Igawa T, Fujimura M, Hamamoto H, Usami R, Yamaguchi I (2003) Expression in cereal plants of genes that inactivate Fusarium mycotoxins. Biosci Biotechnol Biochem 67(4):914-918. https://doi.org/10.1271/ bbb.67.914

Hussein HS, Brasel JM (2001) Toxicity, metabolism, and impact of mycotoxins on humans and animals. Toxicology 167(2):101-134

Jia D, Li J, Liu L, Zhang D, Yang Y, Du G, Chen J (2013) High-level expression, purification, and enzymatic characterization of truncated poly(vinyl alcohol) dehydrogenase in methylotrophic yeast Pichia pastoris. Appl Microbiol Biotechnol 97(3):1113-1120. https://doi.org/10.1007/s0025 3-012-3986-3

Johnson KA (2013) A century of enzyme kinetic analysis, 1913 to 2013. FEBS Lett 587(17):2753-2766. https://doi.org/10.1016/j.febslet.2013.07.012

Kang P, Liao M, Wester MR, Leeder JS, Pearce RE, Correia MA (2008) CYP3A4Mediated carbamazepine (CBZ) metabolism: formation of a covalent CBZ-CYP3A4 adduct and alteration of the enzyme kinetic profile. Drug Metab Dispos 36(3):490-499. https://doi.org/10.1124/dmd.107.016501

Karlovsky P, Suman M, Berthiller F, De Meester J, Eisenbrand G, Perrin I, Oswald IP, Speijers G, Chiodini A, Recker T, Dussort P (2016) Impact of food processing and detoxification treatments on mycotoxin contamination. Mycotoxin Res 32(4):179-205. https://doi.org/10.1007/s12550-016-0257-7

Kleinova M, Zollner P, Kahlbacher H, Hochsteiner W, Lindner W (2002) Metabolic profiles of the mycotoxin zearalenone and of the growth promoter zeranol in urine, liver, and muscle of heifers. J Agric Food Chem 50(17):4769-4776

Liu L, Yang H, Shin HD, Chen RR, Li J, Du G, Chen J (2013) How to achieve high-level expression of microbial enzymes: strategies and perspectives. Bioengineered 4(4):212-223. https://doi.org/10.4161/bioe.24761

Loi M, Fanelli F, Liuzzi VC, Logrieco AF, Mule G (2017) Mycotoxin biotransformation by native and commercial enzymes: present and future perspectives. Toxins. https://doi.org/10.3390/toxins9040111

Love KR, Dalvie NC, Love JC (2017) The yeast stands alone: the future of protein biologic production. Curr Opin Biotechnol 53:50-58. https://doi. org/10.1016/j.copbio.2017.12.010

Mamo G, Thunnissen M, Hatti-Kaul R, Mattiasson B (2009) An alkaline active xylanase: insights into mechanisms of high $\mathrm{pH}$ catalytic adaptation. Biochimie 91(9):1187-1196. https://doi.org/10.1016/j.biochi.2009.06.017

McCormick SP (2013) Microbial detoxification of mycotoxins. J Chem Ecol 39(7):907-918. https://doi.org/10.1007/s10886-013-0321-0

Minervini F, Dell'Aquila ME (2008) Zearalenone and reproductive function in farm animals. Int J Mol Sci 9(12):2570-2584. https://doi.org/10.3390/ijms9 122570

Novozymes A/S. Detoxification of aflatoxin in feed products. European Patent 2252163, 5 March 2009

Novozymes A/S. Detoxification of feed products. World Patent 2009109607, 5 March 2009

Numanoglu E, Yener S, Gokmen V, Uygun U, Koksel H (2013) Modelling thermal degradation of zearalenone in maize bread during baking. Food Addit Contam Part A Chem Anal Control Expo Risk Assess 30(3):528-533. https://doi.org/10.1080/19440049.2012.751629

Peng W, Ko T-P, Yang Y, Zheng Y, Chen C-C, Zhu Z, Huang C-H, Zeng Y-F, Huang J-W, Wang AHJ, Liu J-R, Guo R-T (2014) Crystal structure and substratebinding mode of the mycoestrogen-detoxifying lactonase ZHD from Clonostachys rosea. RSC Adv 4(107):62321-62325. https://doi.org/10.1039/ c4ra12111b

Perry TW, Stob M, Huber DA, Peterson RC (1970) Effect of subcutaneous implantation of resorcylic acid lactone on performance of growing and finishing beef cattle. J Anim Sci 31(4):789-793

Seibert E, Tracy TS (2014) Fundamentals of enzyme kinetics. Meth Mol Biol 1113:9-22. https://doi.org/10.1007/978-1-62703-758-7_2

Shier WT, Shier AC, Xie W, Mirocha CJ (2001) Structure-activity relationships for human estrogenic activity in zearalenone mycotoxins. Toxicon 39(9):1435-1438

Sterner R, Liebl W (2001) Thermophilic adaptation of proteins. Crit Rev Biochem Mol Biol 36(1):39-106. https://doi.org/10.1080/20014091074174

Sun X, He X, Xue K, Li Y, Xu D, Qian H (2014) Biological detoxification of zearalenone by Aspergillus niger strain FS10. Food Chem Toxicol 72:76-82. https ://doi.org/10.1016/j.fct.2014.06.021

Takahashi-Ando N, Kimura M, Kakeya H, Osada H, Yamaguchi I (2002) A novel lactonohydrolase responsible for the detoxification of zearalenone: enzyme purification and gene cloning. Biochem J 365(Pt 1):1-6. https:// doi.org/10.1042/bj20020450

Takahashi-Ando N, Ohsato S, Shibata T, Hamamoto H, Yamaguchi I, Kimura M (2004) Metabolism of zearalenone by genetically modified organisms expressing the detoxification gene from Clonostachys rosea. Appl Environ Microbiol 70(6):3239-3245. https://doi.org/10.1128/ AEM.70.6.3239-3245.2004

Takahashi-Ando N, Tokai T, Hamamoto H, Yamaguchi I, Kimura M (2005) Efficient decontamination of zearalenone, the mycotoxin of cereal 
pathogen, by transgenic yeasts through the expression of a synthetic lactonohydrolase gene. Appl Microbiol Biotechnol 67(6):838-844. https:// doi.org/10.1007/s00253-004-1816-y

Urry WH, Wehrmeister HL, Hodge EB, Hidy PH (1966) The structure of zearalenone. Tetrahedron Lett 7(27):3109-3114

Wilson LL, Borger ML, Peterson AD, Rugh MC, Orley CF (1972) Effects of zeranol, dietary protein level and methionine hydroxy analog on growth and carcass characters and certain blood metabolites in lambs. J Anim Sci 35(1):128-132

Xiang Wang Q, Zhou Y, Yin L, Zhang G, Ma Y (2016) High-level expression of a ZEN-detoxifying gene by codon optimization and biobrick in Pichia pastoris. Microbiol Res 193:48-56. https://doi.org/10.1016/j.micre s.2016.09.004
Yang WC, Hsu TC, Cheng KC, Liu JR (2017) Expression of the Clonostachys rosea lactonohydrolase gene by Lactobacillus reuteri to increase its zearalenone-removing ability. Microb Cell Fact 16(1):69. https://doi.org/10.1186/ s12934-017-0687-8

Yu Y, Wu H, Tang Y, Qiu L (2012) Cloning, expression of a peroxiredoxin gene from Acinetobacter sp. SM04 and characterization of its recombinant protein for zearalenone detoxification. Microbiol Res 167(3):121-126. https:// doi.org/10.1016/j.micres.2011.07.004

Zinedine A, Soriano JM, Molto JC, Manes J (2007) Review on the toxicity, occurrence, metabolism, detoxification, regulations and intake of zearalenone: an oestrogenic mycotoxin. Food Chem Toxicol 45(1):1-18. https:// doi.org/10.1016/j.fct.2006.07.030

\section{Submit your manuscript to a SpringerOpen ${ }^{\odot}$ journal and benefit from:}

- Convenient online submission

- Rigorous peer review

- Open access: articles freely available online

- High visibility within the field

- Retaining the copyright to your article

Submit your next manuscript at $\boldsymbol{\nabla}$ springeropen.com 